\title{
Factors influencing the rate of beach sand wear: Activation layer thickness and sediment durability
}

\author{
M. López, F. Baeza-Brotons, I. López, A.J. Tenza-Abril, L. Aragonés* \\ Dept. of Civil Engineering, University of Alicante, Carretera San Vicent del Raspeig s/n, 03690 Alicante, Spain
}

\section{A R T I C L E I N F O}

Article history

Received 6 November 2018

Received in revised form 13 December 2018

Accepted 13 December 2018

Available online $\mathrm{xxx}$

Editor: Damia Barcelo

\section{Keywords}

Accelerated wear particle test

Beach nourishment

Activation layer

Durability

Aging

\begin{abstract}
A B S T R A C T
The construction of harbours on the coast and/or dams in river courses prevents the contribution of sediments from rivers and ravines to the coastline and interferes with natural coastal dynamics. In the present study, the main objective is to provide information to the coastal engineer to predict and quantify the wear and tear of sand for artificial beach nourishment, as well as the durability of the intervention. For this purpose: (i) the amount of sample used in laboratory tests is related to the actual activation layer due to waves, and (ii) the material durability (aging) is demonstrated. Sands belonging to 9 beaches in the province of Alicante (Spain) were tested and studied, with different sample quantities $(60,75,100,120$ and $150 \mathrm{~g})$, the granulometry, calcimetry and wear (using the accelerated particle wear test, APW). The results showed that (generally) the greater the amount of sample used (activation layer), the greater the mass loss (reduction to size $<0.063 \mathrm{~mm}$ ) during the first cycle of the wear test. This may be due to the fact that the greater the amount of material in suspension (as a consequence of greater energy for the same volume of water), the greater the possibility of collision between particles, and therefore, greater particle wear and greater erosion on the beach. In addition, when the same material was subjected to new wear test cycles, that is, without the addition of new material (as is currently happening on the coasts), the durability of the same was compromised up to its wear limit. Particle wear reduces the median sediment size, which encourages movement towards the off-shore zone. Therefore, the wave energy, the material durability and the median sand diameter are elements to be taken into account in a beach nourishment
\end{abstract}

(C) 2018

\section{Introduction}

From 1980 to the present, important coastal development and modification of river courses have occurred, which has interfered with the natural dynamics of both the coast and rivers. Structures such as ports and dams have a direct impact on the local dynamics of sediments (Aragonés et al., 2016; Newton et al., 2012). For this reason, in the last decade there has been a gradual change in coastal defence techniques, tending towards artificial beach nourishment as a mitigation of erosion (Trembanis and Pilkey, 1998). To minimize the environmental effects caused by the coastal erosion, it is necessary to thoroughly understand each factor involved in the sediments abrasion.

The wear of the particle begins with the grain movement, this happens when the instantaneous force of the fluid is greater than the particle resistance force, which is a function of the particle weight, the angle of the particle at rest, the lifting force and the drag force. This "motion initiation" is defined classically by the empirically obtained Shields curve (Shields, 1936).

Many authors quantify the activation depth (or activation layer), defined as the thickness of the sand column mobilized when it is affected by hydrodynamic processes, mainly waves and sea currents

\footnotetext{
* Corresponding author.

Email address: laragones@ua.es (L. Aragonés)
}

(Ciavola et al., 1998; Fucella and Dolan, 1996; King, 1951; Sunamura and Kraus, 1984). These studies allow a better understanding of near-shore erosion processes, as well as the prediction of beach erosion during storms. In the literature, two methods based on empirical equations that relate activation depth to wave height at break stand out: (i) those proposed by Anfuso et al. (2000), King (1951) and Sunamura and Kraus (1984) that apply to gently sloping beaches, where the disturbance depth is approximately $1-4 \%$ of the significant wave height at break; and (ii) the relationship proposed by Ciavola et al. (1998), Jackson and Malvarez (2002), Jackson and Nordstrom (1993) and Otvos (1965) for steep beaches, with activation values ranging from 18 to $40 \%$ of significant wave height at break. Ciavola et al. (2013) and Ciavola et al. (2006) carried out channel tests to study the thickness of the sand layer moved, and modelled nourished beaches, with and without protection, and beaches with and without drainage systems. However, until Bertin et al. (2008) none of the cited authors takes into account the wave incidence angle for the study of the activation layer.

Furthermore, Anfuso et al. (2001) pointed out that the most important intrinsic factors controlling the stability of nourished beaches are the designed beach profile gradient, the borrowed sediment size and density, as well as porosity (Román-Sierra et al., 2014). Eitner (1996), in a study of beach nourishment in Germany, found that grain density strongly influenced the longevity of beach fill, even more than the sediment grain size. Mineralogical composition is another 
important aspect that can influence sediment weathering (Roberts et al., 1998). However, although important, it has been demonstrated that mineralogical composition is not a fundamental factor in the shoreline retreat (Pagán et al., 2018a).

Marine sediments are composed of a high proportion of carbonate, which is the second most abundant element in the world's oceans (Milliman and Syvitski, 1992). Quartz and bioclastic carbonate are the main components of the sediment (De Falco et al., 2003). López et al. (2016b) demonstrated the wave energy's effect on the wear of the quartz mineral fraction. Wear increases roundness and decreases grain size, a phenomenon generally attributed to the differential wear rates of coarse and fine grains. The main consequence of this wear is the decrease in sediment size until it becomes so small that it exceeds the imaginary limit called depth of closure (DoC), and therefore not returning to the on-shore zone (Aragonés et al., 2016), resulting in beach erosion.

Another factor to consider is material fatigue, which refers to a phenomenon whereby the material is broken under long-lasting dynamic stresses (Attewell and Farmer, 1973). This is the cause of $90 \%$ of failures in metallic origin components (Dieter et al., 1988). The term fatigue has also been defined as the tendency of the material to fail or the process of damage accumulation due to cyclic loads (Bagde and Petroš, 2005). Often, these cyclic loads also cause failures in other fragile materials, such as rocks, with stress levels lower than their resistance under monotonous conditions (Attewell and Farmer, 1973; Erarslan and Williams, 2012; Evans and Fuller, 1974; Lantsoght et al., 2016). However, the study of fatigue in stony or rocky materials is much more limited (Haghgouei et al., 2018). One of the main objectives of stone fatigue research is to establish a relationship between the number of cycles and the reduction in the amplitude of the applied effort. For quasi-brittle materials, such as concrete and rocks, cracking is the major cause of failure (Erarslan and Williams, 2012). In fact, the existence of fractures in rocks significantly affects their resistance to fatigue (Li et al., 2001; Liu et al., 2018), although the role of microstructural aspects must not be underestimated (Benedetti and Gulizzi, 2018). Natural granular materials cannot be considered as homogeneous and continuous due to microcracks, pores, grain limits, etc. (Justo et al., 2017). In these defects, the greatest efforts are concentrated, generating the beginning and propagation of the cracking and, at other times, causing fragile breaks in the material (Chiva et al., 2018; Pagán et al., 2018b). Studies on the influence of fatigue on beach sand are practically non-existent. However, recently a study carried out by López et al. (2016a) simulated the wear and tear of the sand particles generated by the waves, which may be linked to fatigue on beach sand.

This study explores the connection between wear and tear of sand particles and their durability. To achieve this, the following objectives have been set: (i) relate the amount of sample used in accelerated wear tests to the activation layer, and (ii) demonstrate the durability of the beach sand. For this purpose, the accelerated particle wear test (APW) proposed by López et al. (2016a) was used. The goal is to provide the coastal engineer with the tools to quantify the wear and tear of the sands used in beach nourishments and their durability over time.

\section{Study area}

The study area is located in south-eastern Spain, on the coast of the Mediterranean Sea. As can be seen in Fig. 1 the nine beaches studied in this paper are located along the entire coast of the province of Alicante (Spain), which has a total length of $244 \mathrm{~km}$. The area is a coastal plain in the eastern part of the external zone of the Baetic mountain range called Pre-Baetic domain. The most important reliefs correspond to limestones and loams of the Cretaceous. The area is characterised by a semi-arid Mediterranean climate and a low annual precipitation rate (Valdes-Abellan et al., 2017). Mediterranean tides are not constant over time, they can be classified, by considering the sea type into diurnal, semidiurnal and mixed (Ecolevante, 2006).

The nine studied beaches are located in seven of the twenty municipalities on the coast of the Alicante province (from north to south): Deveses, Molinos y Palmeras and Marineta Casiana, located in the municipality of Dénia; El Portet de Moraira in the municipality

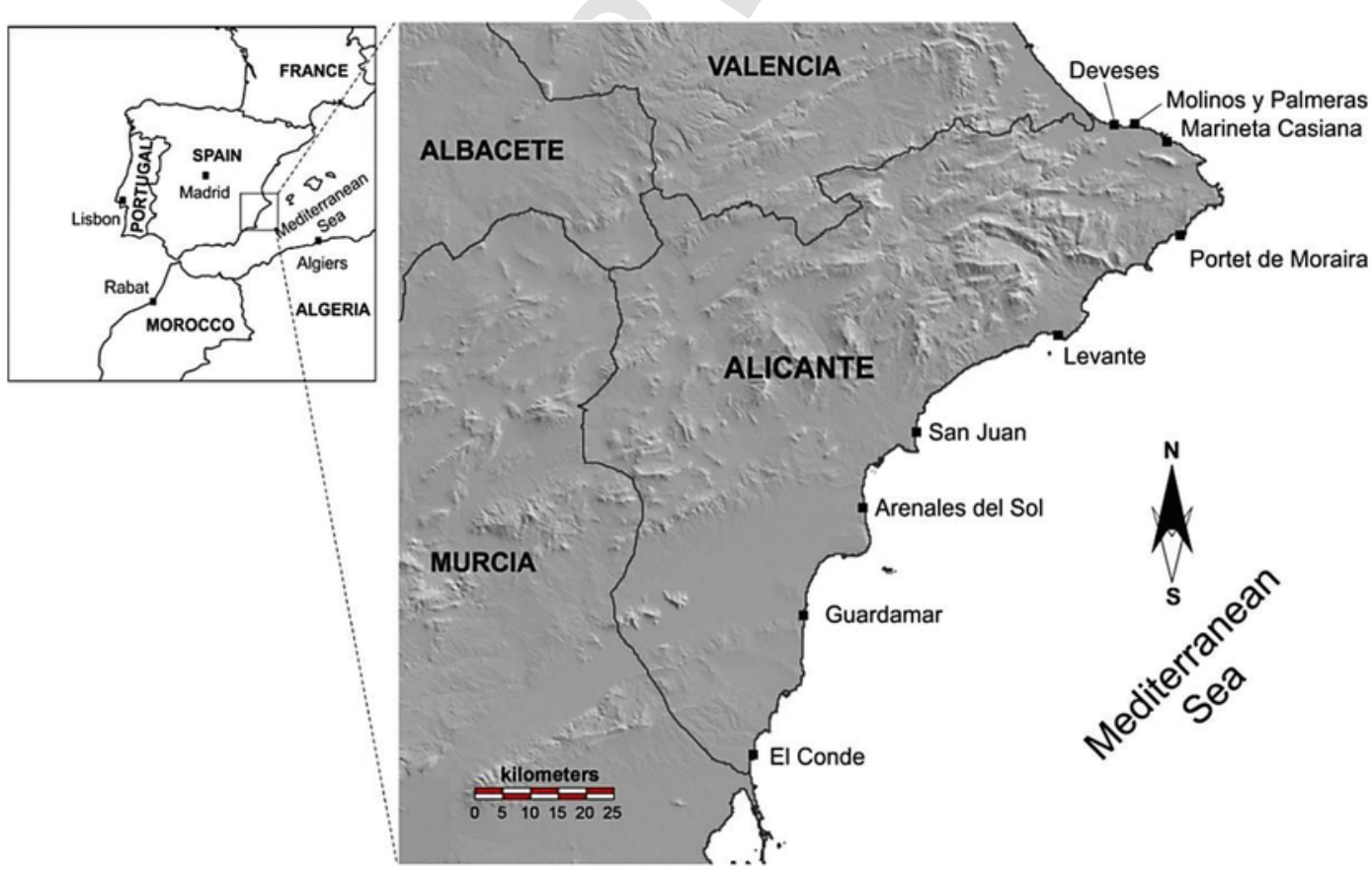

Fig. 1. Location of the analysed beaches. 
of Teulada; Levante beach in Benidorm; San Juan beach in the municipality of Alicante; Arenales del Sol in the municipality of Elche, Guardamar beach in the municipality Guardamar; and, El Conde beach in the municipality of Pilar de la Horadada (Aragonés et al., 2015; Pagán et al., 2016; Pagán et al., 2017; Palazón et al., 2016; Aragonés et al., 2015; Chiva et al., 2018; Pagán et al., 2017).

\section{Methodology}

Knowledge of the causes of coastal erosion requires an extensive study of the different factors involved and their interrelations. In this study, twenty-two samples belonging to nine different beaches were analysed, which were subjected to the APW test (López et al., 2016a) using different sand quantities $(60 \mathrm{~g}, 75 \mathrm{~g}, 100 \mathrm{~g}, 120 \mathrm{~g}$ and $150 \mathrm{~g})$. From the tests the following parameters were obtained:

- Cycles (n): refers to the number of APW cycles needed to reduce the total grain sample to sizes $<0.063 \mathrm{~mm}$, indicating the end of its useful life and thus of the test.

- D0 and Dn: refer to median sediment size $\left(D_{50}\right)$ before undergoing the APW test, in the first cycle (0), and in the last cycle (n), once the APW test has been carried out. In both cases, the results include all the particles that comprise the simple

- D01, Du and D0n: refer to the diameter loss in percentage (\%) between cycle 0 and cycle $1(01)$, in the last cycle $(\mathrm{u})$, and between cycle 0 and cycle $n(0 \mathrm{n})$ of the APW test.

- M0 and Mn: refer to weight in grams before cycle 0 and after cycle $\mathrm{n}$ of the APW test. In neither case, were the particles $0.063 \mathrm{~mm}$ computed.

- M01, Mu and Mnn: refer to weight loss in percentage between cycle 0 and cycle $1(01)$, in the last cycle (u), and between cycle " $n$ " and " $n$ " (nn) of the APW test

- $\mathrm{CaCO}_{3}$ : refers to the percentage of calcium carbonate in suspension in the water accumulated during the " $n$ " cycles of the APW test.

To characterise the aggregates under analysis, the study was broken down as follows: i) sampling; ii) granulometry; iii) calcimetry; and iv) accelerated particle wear test.

\subsection{Sampling}

All the analysed samples were taken directly from the beach. For sampling, the top $10 \mathrm{~cm}$ layer of sand was removed, and then a sample of $500 \mathrm{~g}$ of sand was taken. Four samples were taken at evenly distributed points along the beach ( 3 from the shoreline - centre and ends and 1 from the centre of the dry beach). The samples were homogenised and divided by quartering for each test in the laboratory. In addition, the granulometry of the 4 samples from the same beach was compared and it was found to be very similar.

\subsection{Granulometry}

The granulometric tests were carried out following the UNE 103 101: 1995 standard, complemented by UNE 7050-2: 1997 and UNE 103 100: 1995. At the start and after each cycle of the APW test: the median particle size $\left(D_{50}\right)$ was calculated in two different ways: (i) with the whole sample, and (ii) by removing the fine part of the sample (sizes $<0.063 \mathrm{~mm}$ ). The reduction of $\mathrm{D}_{50}$ and loss of mass (particles $<0.063 \mathrm{~mm}$ in size) after each cycle ( $\mathrm{mm}$ and \%).

\subsection{Calcimetry}

The increase in the percentage of calcium carbonate suspended in water after each APW test cycle, as a consequence of the loss of this component in the sands, was determined by Bernard's calcimeter method (UNE 103 200: 1993).

\subsection{Accelerated particle wear test (APW)}

To simulate the erosion behaviour of sand particles in the beach swash zone, the accelerated wear test proposed by López et al. (2016a) was used. In this test, different quantities of beach sand $(60 \mathrm{~g}, 75 \mathrm{~g}$, $100 \mathrm{~g}, 120 \mathrm{~g}$ and $150 \mathrm{~g}$ ) and $500 \mathrm{ml}$ of sea water (from Cabo de las Huertas (Alicante), with a $\mathrm{CaCO}_{3}$ content of $0.02 \%$ ) were poured into a magnetic stirrer at $1600 \mathrm{rpm}$ in 24 -hour cycles. We used the number of cycles applied to each sample needed to reduce the particle size to $<0.063 \mathrm{~mm}$ as a reference for determining the particle's wear resistance.

\section{Results and discussion}

The activation layer in the beach sediments has a direct relationship to the wave energy (Ciavola et al., 2013; Ciavola et al., 2006) and therefore can be one of the factors responsible for coastline erosion. The first analysis performed in this research (Table 1) focuses on the loss of material following the first test cycle after testing with the accelerated wear particle test (AWPT). The samples with higher initial mass are those where greater mass loss was observed - e.g. Portet de Moraira, which loses $67.4 \%$ of its mass in the first cycle (M01) and $150 \mathrm{~g}$ of initial mass, while the same beach tested with $75 \mathrm{~g}$ loses only $6.4 \%$ ( $>60 \%$ of difference). Another example to highlight is Arenales del Sol, tested with $150 \mathrm{~g}$ and $75 \mathrm{~g}$, the mass loss after the first cycle was $60.7 \%$ and $7.7 \%$ respectively (Table 1 ). In general, the greater the amount of sample used in the APW test, the greater the loss of mass during the first cycle for the same beach. The results show that the energy reduction to protect the coastline is effective since it was demonstrated that the greater the energy, the greater the wear of the particles. Thus, the coastal engineer can shorten the coastline erosion reducing the wave energy, and as a result, the activation layer is also reduced. This process is usually carried out by the coastal engineer with the construction of breakwaters or increasing the median size of the beach sediments $\left(\mathrm{D}_{50}\right)$ (Rosenzweig et al., 2011; Sterr, 2008; Titus et al., 2009). However, using the same amount of sample does not imply the same mass loss during the first APW test cycle if the samples are from different sources (beaches). As an example, El Conde and Deveses tested with $100 \mathrm{~g}$ of initial mass $(\mathrm{D} 0=0.238 \mathrm{~mm}$ and $\mathrm{D} 0=0.208 \mathrm{~mm}$, respectively) resulted in $56 \%$ and $12.2 \%$ of mass loss in the first cycle, respectively. This result indicates that higher D0 does not imply slower particle wear. The type of material might have a considerable influence on the amount of the sample lost in the first cycle, even more than its $\mathrm{D}_{50}$.

Extrapolating the laboratory results to real scale, the greater or lesser amount of sample used in the test can be directly related to the thickness of the activation layer that can be in suspension due to the waves. According to several studies, it can be deduced that the greater the wave energy that affects the beach, the higher is the activation layer thickness (Ciavola et al., 2013; Ciavola et al., 2006) and therefore, it results in a greater particle wear, as was observed at the laboratory scale. In addition, since the amount of sediment in suspension is greater — when there is higher energy — for the same volume 
Table 1

Summary of data obtained from APW test of $60,75,100,120$ and $150 \mathrm{~g}$ samples of initial mass.

\begin{tabular}{|c|c|c|c|c|c|c|c|c|c|c|c|c|}
\hline \multicolumn{2}{|c|}{ Samples name ID/name/(grams) } & \multirow[t]{3}{*}{ Cycles (n) } & \multicolumn{8}{|c|}{ Granulometry } & \multicolumn{2}{|r|}{$\mathrm{CaCO}_{3}$} \\
\hline & & & \multicolumn{4}{|l|}{$\mathrm{D}_{50}$} & \multicolumn{5}{|l|}{ Mass } & \\
\hline & & & D0 & Dn & D01 & $\mathrm{Du}$ & M0 & $\mathrm{Mn}$ & M01 & M12 & $\mathrm{Mu}$ & \\
\hline & & & $\mathrm{mm}$ & $\mathrm{mm}$ & $\%$ & $\%$ & $\mathrm{~g}$ & $\mathrm{~g}$ & $\%$ & $\%$ & $\%$ & $\%$ \\
\hline 1 & Deveses (60) & 6 & 0.194 & 0.028 & 7.0 & 69.8 & 59.7 & 3.2 & 4.0 & 6.6 & 90.1 & 1.08 \\
\hline 2 & Deveses (75) & 3 & 0.198 & 0.027 & 3.6 & 61.0 & 74.5 & 1.6 & 5.5 & 58.5 & 94.6 & 3.19 \\
\hline 3 & Deveses (100) & 3 & 0.208 & 0.064 & 19.2 & 44.7 & 98.2 & 39.03 & 12.2 & 28.8 & 36.4 & 0.02 \\
\hline 4 & El Conde (60) & 6 & 0.233 & 0.035 & 7.4 & 79.8 & 59.2 & 7.4 & 14.1 & 3.1 & 82.1 & 2.88 \\
\hline 5 & El Conde (75) & 4 & 0.236 & 0.028 & 5.6 & 35.5 & 74.7 & 0.5 & 10.2 & 18.0 & 96.8 & 0.02 \\
\hline 6 & El Conde (100) & 1 & 0.238 & 0.077 & 67.6 & 67.6 & 99.2 & 43.7 & 56.0 & & 56.0 & 0.02 \\
\hline 7 & Guardamar (60) & 7 & 0.238 & 0.03 & 0.5 & 57.9 & 59.7 & 5.3 & 5.5 & 7.9 & 80.9 & 2.51 \\
\hline 8 & Guardamar (75) & 3 & 0.249 & 0.033 & 41.6 & 75.5 & 74.3 & 5.0 & 8.1 & 3.8 & 92.4 & 6.62 \\
\hline 9 & Guardamar (100) & 3 & 0.246 & 0.069 & 16.9 & 55.0 & 97.4 & 41.6 & 10.4 & 16.0 & 43.3 & 0.02 \\
\hline 10 & Marineta Casiana (60) & 7 & 0.268 & 0.036 & 3.6 & 14.9 & 59.8 & 16.9 & 5.9 & 1.3 & 5.4 & 0.02 \\
\hline 11 & Marineta Casiana (75) & 4 & 0.279 & 0.041 & 5.6 & 81.8 & 75.0 & 7.4 & 3.9 & 3.5 & 88.0 & 0.02 \\
\hline 12 & Marineta Casiana (100) & 7 & 0.268 & 0.027 & 13.0 & 50.0 & 99.4 & 1.4 & 8.7 & 6.7 & 96.6 & 0.02 \\
\hline 13 & Molinos y Palmeras (75) & 4 & 0.322 & 0.029 & 12.0 & 70.9 & 74.8 & 2.7 & 7.5 & 34.9 & 93.6 & 8.57 \\
\hline 14 & Molinos y Palmeras (100) & 10 & 0.365 & 0.03 & 44.2 & 32.0 & 99.0 & 9.5 & 41.4 & 0.5 & 72.2 & 3.38 \\
\hline 15 & San Juan (75) & 5 & 0.22 & 0.069 & 2.7 & 36.9 & 75.0 & 30.2 & 3.7 & 8.5 & 33.1 & 0.00 \\
\hline 16 & San Juan (100) & 9 & 0.267 & 0.035 & 20.4 & 28.8 & 99.1 & 2.9 & 29.3 & 2.7 & 92.5 & 2.92 \\
\hline 17 & Portet de Moraira (75) & 9 & 0.313 & 0.039 & 5.3 & 75.4 & 74.9 & 3.2 & 6.4 & 4.3 & 92.7 & 4.97 \\
\hline 18 & Portet de Moraira (150) & 12 & 0.327 & 0.033 & 88.6 & 2.7 & 149.1 & 33.4 & 67.4 & 0.5 & 9.9 & 0.99 \\
\hline 19 & Arenales del Sol (75) & 6 & 0.242 & 0.051 & 6.4 & 27.0 & 75.0 & 25.6 & 7.7 & 8.2 & 26.2 & 10.0000000000 \\
\hline 20 & Arenales del Sol (150) & 7 & 0.273 & 0.026 & 84.9 & 6.9 & 149.4 & 1.7 & 60.7 & 4.7 & 61.9 & 2.87 \\
\hline 21 & Levante $(75)$ & 5 & 0.321 & 0.088 & 1.0 & 59.2 & 75.0 & 40.4 & 2.6 & 1.3 & 38.2 & 1.36 \\
\hline 22 & Levante (120) & 7 & 0.288 & 0.031 & 34.2 & 25.9 & 119.9 & 8.8 & 46.5 & 0.2 & 79.1 & 2.11 \\
\hline
\end{tabular}

of water, there will be more possibilities of particles colliding with each other, leading to greater particle wear, and therefore higher beach erosion.

We already know that, after the first APW test cycle, a mass sample fraction is lost (Table 1). In the case of Molinos y Palmeras and Arenales del Sol (100g and $150 \mathrm{~g}$ of initial mass, respectively) they start the next cycle (2nd cycle) with $57.97 \mathrm{~g}$ and $58.30 \mathrm{~g}$, respectively. These values are similar to the beaches that begin the APW test with $60 \mathrm{~g}$ and they can be compared - same mass, from different cycles. Thus, the samples with $60 \mathrm{~g}$ of initial mass before the APW test, present a mass loss lower than $15 \%$ in the first APW test cycle, which is similar to the values observed in the samples mentioned above, namely Molinos y Palmeras and Arenales del Sol $(0.5 \%$ and $4.7 \%$ of mass loss, respectively) in the second test cycle. The results might indicate that the initial sand mass loss is mainly due to the following reasons:

(i) fragile bonds in the sand grains that provoke an easy separation into different components due to the wave energy and turn it into silt (Chiva et al., 2018); and;

(ii) An initial particle wear or wear of more fragile particles and the remaining material persist for a longer period and it gradually loses the median grain size.

The results indicate that coastal engineers should evaluate the initial mass loss in the sand grains and the formation of sizes smaller than $0.063 \mathrm{~mm}$ instead of evaluating the loss of the material smaller than $0.063 \mathrm{~mm}$ during the first storms that occurs in the beach after being nourished.

Therefore, if, as can be observed in many of the beaches analysed, the greatest losses occur at the beginning of the wear test, what is the explanation for the faster erosion of the coastline is faster in recent years? The first answer is that the energy of incident waves on the beaches has increased due to, among other causes, global warming (Nováčková and Tol, 2018). However, in previous studies carried out on the analysed beaches (Chiva et al., 2018; Pagán et al., 2017; Pagán et al., 2018a; Pagán et al., 2018b) it was observed that the energy and frequency of the waves have hardly changed over time (López and Gutiérrez, 1982; Pagán et al., 2016; Romero Diaz et al., 1992; Confederación Hidrográfica del Segura, 2007). Thus, the unresolved question of the increase in the speed of erosion could be addressed via the concept of durability (aging, fatigue) of the material.

The change of sand properties with increasing time is often referred to as sand aging (Michalowski et al., 2018). As can be seen in Table 1 there are samples that with the same initial mass and similar median sizes D0 (which would imply in a real scale, the same energy of the incident wave) results in completely different initial mass losses. For example, San Juan and Marineta Cassiana (100g of initial mass and initial median sizes of $0.267 \mathrm{~mm}$ and $0.268 \mathrm{~mm}$, respectively). The mass loss of these samples after the first cycle was $29.3 \%$ in San Juan and 8.7\% in Marineta Cassiana.

As mentioned previously, this can be explained in terms of the material durability because the material suddenly reduces its average diameter at a given point in time to sizes smaller than $0.063 \mathrm{~mm}$ (Fig. 2). The only difference in each material is the cycle number after the APW test.

The causes of the different behaviour between these beaches can be the effect of the dissolution after a period of time (Hu and Hueckel, 2007a) and the hypothesis for the aging produced in the grains. This hypothesis, as referred to by Michalowski and Nadukuru (2012), shows the dependence of microscopic fracturing in time due to maintained loads and usually referred to as aging. When it comes to grains that remain in stationary conditions after being vibro-compacted, there is a change in the properties of the grains over time, microscopically observing the microfracturing of their surface. This microfracturing has an important consequence over time. However, in the case of sands that remain in continuous movement - shock and dissolution - the continuous wear caused in each grain will initiate the microcracking and it will be responsible for the reduction in grain size. Additionally, the contact process between rigid grains and deformable grains (Hu and Hueckel, 2007a) and the cracking of grains induced by the spontaneous mineral dissolution ( $\mathrm{Hu}$ and Hueckel, 


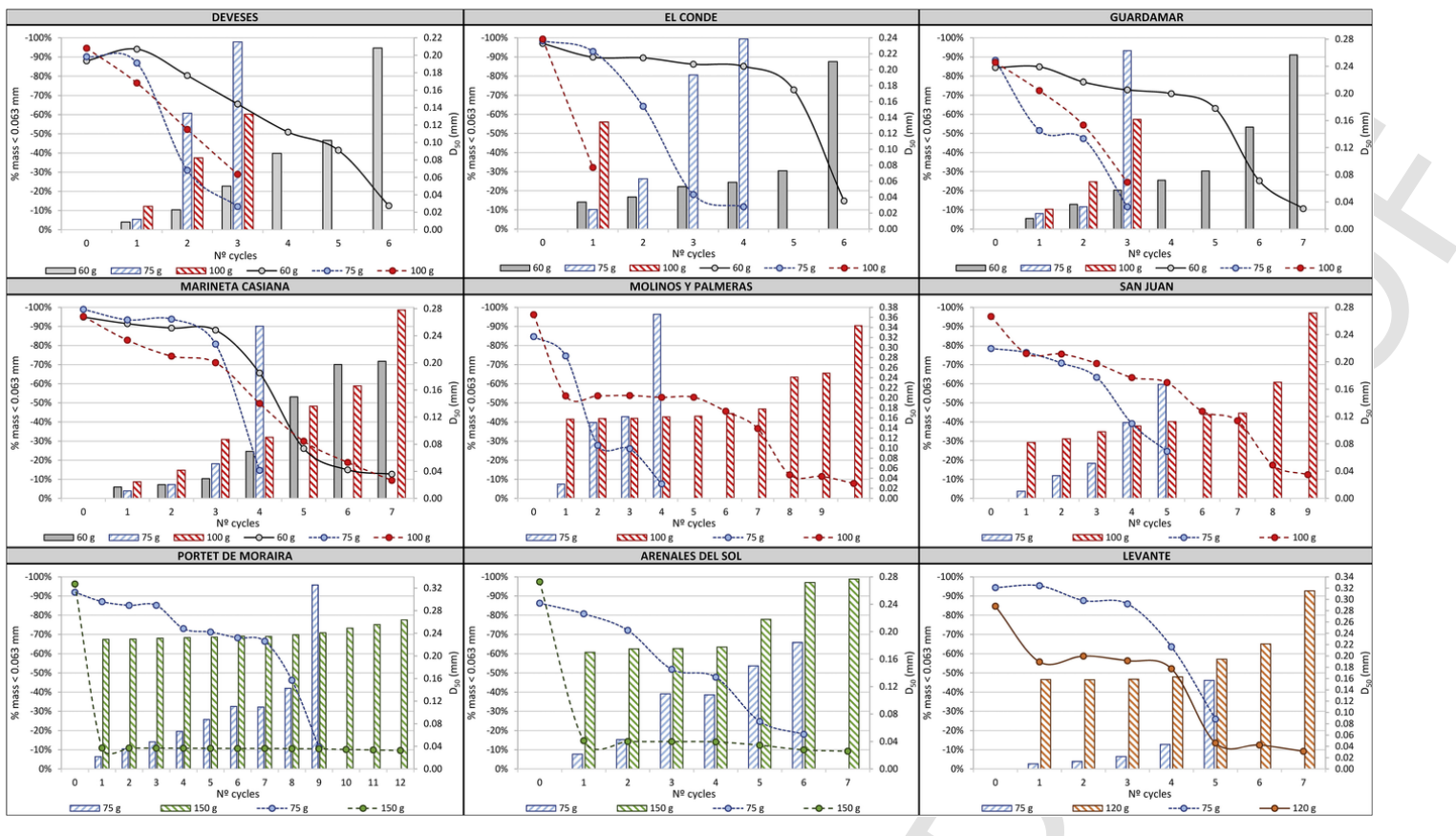

Fig. 2. Evolution of median sediment size and percentage of mass $<0.063 \mathrm{~mm}$.

2007b) that is associated with microcracking (Brace et al., 1966) results in the progressive reduction of the grain size.

Therefore, two beaches of the same grain sediment size and wave energy will behave differently on a real scale — different coastline erosion - if the material of each is at a different stage of the life cycle (Pagán et al., 2018a). Thus, if we accept the hypothesis of the material's age, we can explain the acceleration of the beach erosion in the last decades, since, due to the construction of dams and channels, the amount of natural contributions of sediment to the sea by rivers and ravines has been reduced (Aragonés et al., 2016; Newton et al., 2012). Therefore, as there is no sediment renewal, it is the same material that is continuously exposed to the waves. This causes the material to reach its limit of durability, becoming silty and being transported by currents and gravitational movements towards the abyssal plains (Aragonés et al., 2016).

\section{Conclusions}

After analysing the sand samples from beaches in the province of Alicante (Spain). A summary of the general conclusions from the presented research are:

- In general, the greater the amount of sample used in the tests, the greater mass loss occurs during the first wear cycle using the accelerated particle wear test. This may be caused because, the greater the amount of suspended material, the greater the energy for the same volume of water. This fact produces more possibilities of collision between particles and consequently greater particle wear that means a greater beach erosion.

- The increase of beach erosion observed in recent decades could be strongly influenced by the durability of the sands. The lack of natural contribution of sediment caused by anthropic actions (dams, channels, etc.) has as a direct consequence on the aging of the sediment. The same material is exposed continuously to the swell of the waves up to its limit of wear (until reaching the size of silts that are transported by currents and gravitational movements towards abyssal plains).
Therefore, the wave energy, the durability of the material that composes the sediment and the median diameter of the sandy fraction are elements to be taken into account in a beach nourishment. Therefore, studies that relate the accelerated particle wear test with the evolution of the coastline are essential. Efforts to reduce the activation layer and to improve the durability of the material are also indispensable to preserve the coastline.

\section{Acknowledgements}

This work was partially supported by the Universidad de Alicante through the project "Estudio sobre el desgaste y composición de los sedimentos y su influencia en la erosión de las playas españolas" (GRE16-09).

\section{References}

Anfuso, G., Gracia, F., Andrés, J., Sánchez, F., Del Río, L., López-Aguayo, F., 2000. Depth of disturbance in mesotidal beaches during a single tidal cycle. J. Coast. Res. 446-457.

Anfuso, G., Martínez, J.A., Gracia, F.J., 2001. Longshore Distribution of Morphodynamic Beach States in an Apparently Homogeneous Coast (Chipiona-Rota, SW Spain). 1381-1392.

Aragonés, L., García-Barba, J., García-Bleda, E., López, I., Serra, J., 2015. Beach nourishment impact on Posidonia oceanica: case study of Poniente Beach (Benidorm, Spain). Ocean Eng. 107, 1-12.

Aragonés, L., Pagán, J.I., López, M.P., García-Barba, J., 2016. The impacts of Segura River (Spain) channelization on the coastal seabed. Sci. Total Environ. 543 (Part A), 493-504.

Bertin, X., Castelle, B., Anfuso, G., Ferreira, , 2008. Improvement of sand activation depth prediction under conditions of oblique wave breaking. Geo-Mar. Lett. 28 (2), 65-75.

Brace, W.F., Paulding, B.W., Scholz, C., 1966. Dilatancy in the fracture of crystalline rocks. J. Geophys. Res. 71 (16), 3939-3953.

Chiva, L., Pagán, J.I., López, I., Tenza-Abril, A.J., Aragonés, L., Sánchez, I., 2018. The effects of sediment used in beach nourishment: study case El Portet de Moraira beach. Sci. Total Environ. 628-629, 64-73.

Ciavola, P., Dias, N., Ferreira, O., Taborda, R., Dias, J., 1998. Fluorescent sands for measurements of longshore transport rates: a case study from Praia de Faro in southern Portugal. Geo-Mar. Lett. 18 (1), 49-57. 
Ciavola, P., Nadalini, F., Ardone, V., 2006. Depth of sand activation on protected and non-protected nourished beaches: a laboratory study in a large-scale wave flume. In: Coastal Dynamics 2005: State of the Practice. pp. 1-14.

Ciavola, P., Contestabile, P., Aristodemo, F., Vicinanza, D., 2013. Beach sediment mixing under drained and undrained conditions. J. Coast. Res. 65 (sp2), $1503-1508$.

2007. Plan de defensa de 1987 frente a avendidas en la cuenca del Segura. XX Aniversario (Murcia). In: Confederación Hidrográfica Del Segura (Ed.), CONFEDERACIÓN HIDROGRÁFICA DEL SEGURA.

De Falco, G., Molinaroli, E., Baroli, M., Bellacicco, S., 2003. Grain size and compositional trends of sediments from Posidonia oceanica meadows to beach shore, Sardinia, western Mediterranean. Estuar. Coast. Shelf Sci. 58 (2), 299-309.

Ecolevante, 2006. Estudio ecocartográfico del litoral de las provincias de Alicante y Valencia, Dirección General de Costas, Ministerio de Medio Ambiente, Spain. Available online: http://www.mapama.gob.es/es/costas/temas/ proteccion-costa/ecocartografias/ecocartografia-alicante.aspx.

Eitner, V., 1996. The effect of sedimentary texture on beach fill longevity. J. Coast. Res. 12 (2), 447-461.

Fucella, J.E., Dolan, R., 1996. Magnitude of subaerial beach disturbance during northeast storms. J. Coast. Res. 420-429.

Hu, L.B., Hueckel, T., 2007. Coupled chemo-mechanics of intergranular contact: toward a three-scale model. Comput. Geotech. 34 (4), 306-327.

Hu, L.B., Hueckel, T., 2007. Creep of saturated materials as a chemically enhanced rate-dependent damage process. Int. J. Numer. Anal. Methods Geomech. 31 (14), $1537-1565$.

Jackson, D., Malvarez, G., 2002. A new, highresolution 'depth of disturbance' instrument (SAM) for use in the surf zone. J. Coast. Res. 36, 406-413.

Jackson, N.L., Nordstrom, K.F., 1993. Depth of activation of sediment by plunging breakers on a steep sand beach. Mar. Geol. 115 (1-2), 143-151.

King, C., 1951. Depth of disturbance of sand on sea beaches by waves. J. Sediment. Res. 21 (3), 131-140.

López, F., Gutiérrez, J.D., 1982. Estimación de la erosión y aterramientos de los embalses en la cuenca hidrográfica del río Segura. In: Cuadernos de investigación geográfica. pp. 3-18.

López, I., López, M., Aragonés, L., García-Barba, J., López, M.P., Sánchez, I., 2016. The erosion of the beaches on the coast of Alicante: study of the mechanisms of weathering by accelerated laboratory tests. Sci. Total Environ. 566-567, 191-204.

López, M., López, I., Aragonés, L., Serra, J.C., Esteban, V., 2016. The erosion on the east coast of Spain: wear of particles, mineral composition, carbonates and Posidonia oceanica. Sci. Total Environ. 572, 487-497.

Michalowski, R.L., Nadukuru, S.S., 2012. Static fatigue, time effects, and delayed increase in penetration resistance after dynamic compaction of sands. J. Geotech. Geoenviron. 138 (5), 564-574.

Michalowski, R.L., Wang, Z., Park, D., Nadukuru, S.S., 2018. Static fatigue or maturing of contacts in silica sand. In: Proceedings of the GeoShanghai International Conference. pp. 911-918.

Milliman, J.D., Syvitski, J.P.M., 1992. Geomorphic/tectonic control of sediment discharge to the ocean: the importance of small mountainous rivers. J. Geol. 100 (5), 525-544.

Newton, A., Carruthers, T.J.B., Icely, J., 2012. The coastal syndromes and hotspots on the coast. Estuar. Coast. Shelf Sci. 96, 39-47.

Nováčková, M., Tol, R.S.J., 2018. Effects of sea level rise on economy of the United States. J. Environ. Econ. Policy 7 (1), 85-115.

Otvos, E.G., 1965. Sedimentation-erosion cycles of single tidal periods on Long Island Sound beaches. J. Sediment. Res. 35 (3), 604-609.
Pagán, J.I., Aragonés, L., Tenza-Abril, A.J., Pallarés, P., 2016. The influence of anthropic actions on the evolution of an urban beach: case study of Marineta Cassiana beach, Spain. Sci. Total Environ. 559, 242-255.

Pagán, J.I., López, I., Aragonés, L., Garcia-Barba, J., 2017. The effects of the anthropic actions on the sandy beaches of Guardamar del Segura, Spain. Sci. Total Environ. 601, 1364-1377.

Pagán, J.I., López, M., López, I., Tenza-Abril, A.J., Aragonés, L., 2018. Causes of the different behaviour of the shoreline on beaches with similar characteristics. Study case of the San Juan and Guardamar del Segura beaches, Spain. Sci. Total Environ. $634,739-748$.

Pagán, J.I., López, M., López, I., Tenza-Abril, A.J., Aragonés, L., 2018. Study of the evolution of gravel beaches nourished with sand. Sci. Total Environ. 626, 87-95.

Palazón, A., Aragonés, L., López, I., 2016. Evaluation of coastal management: study case in the province of Alicante, Spain. Sci. Total Environ. 572, 1184-1194.

Roberts, J., Jepsen, R., Gotthard, D., Lick, W., 1998. Effects of particle size and bulk density on erosion of quartz particles. J. Hydraul. Eng. 124 (12), 1261-1267.

Román-Sierra, J., Muñoz-Perez, J.J., Navarro-Pons, M., 2014. Beach nourishment effects on sand porosity variability. Coast. Eng. 83, 221-232.

Romero Diaz, M.A., López Bermúdez, F., Cabezas, F., 1992. Erosion and fluvial sedimentation in the River Segura basin (Spain). Catena 19 (3), 379-392.

Rosenzweig, C., Solecki, W.D., Blake, R., Bowman, M., Faris, C., Gornitz, V., Horton, R., Jacob, K., Leblanc, A., Leichenko, R., 2011. Developing coastal adaptation to climate change in the New York City infrastructure-shed: process, approach, tools, and strategies. Clim. Chang. 106 (1), 93-127.

Shields, A., 1936. Application of similarity principles and turbulence research to bed-load movement. In: Ott, W.P., Uchelen, J.C. (Eds.), Mitt. Preuss. Verschsanst., Berlin. Wasserbau Schiffbau. California Institute of Technology, Pasadena, CA, Report No. 167, (43 pp.)

Sterr, H., 2008. Assessment of vulnerability and adaptation to sea-level rise for the coastal zone of Germany. J. Coast. Res. 380-393.

Sunamura, T., Kraus, N.C., 1984. Prediction of average mixing depth of sediment in the surf zone. Mar. Geol. 62 (1-2), 1-12.

Titus, J.G., Hudgens, D.E., Trescott, D.L., Craghan, M., Nuckols, W.H., Hershner, C.H., Kassakian, J., Linn, C.J., Merritt, P.G., Mccue, T., 2009. State and local governments plan for development of most land vulnerable to rising sea level along the US Atlantic coast. Environ. Res. Lett. 4 (4), 044008.

Trembanis, A.C., Pilkey, O.H., 1998. Summary of beach nourishment along the US Gulf of Mexico shoreline. J. Coast. Res. 14 (2), 407-417.

Une 103 100: 1995, 1995. Sample preparation for soil tests. Standardization Technical Committee AEN/CTN 103 - Geotechnics. Available online: http://www.aenor.es/ aenor/normas/normas/fichanorma.asp?tipo $=\mathrm{N} \&$ codigo $=\mathrm{N} 0007827 \mathrm{\#}$ WIHClfnhCUk, (8).

Une 103 101: 1995, 1995. Particle size analysis of a soil by screening. Standardization Technical Committee AEN/CTN 103 - Geotechnics. Available online: http:// www.aenor.es/aenor/normas/normas/fichanorma.asp?tipo $=\mathrm{N} \&$ codigo $=$ N0007828\#.WIHC_vnhCUk, (10)

Une 103 200: 1993, 1993. Determination of carbonate content in soils. Standardization Technical Committee AEN/CTN 103 - Geotechnics. Available online: https:// www.aenor.com/normas-y-libros/buscador-de-normas/UNE?c=N0007837, (6).

Une 7050-2: 1997, 1997. Test sieves. Metal wire cloth, perforated metal plate and electroformed sheet. Nominal size of openings. Standardization Technical Committee AEN/CTN 7 - Materials testing. Available online: http://www.aenor.es/aenor/ normas $/$ normas $/$ fichanorma.asp?tipo $=\mathrm{N \&}$ codigo $=$ N0000151\#. WIHCyfnhCUk, (8).

Valdes-Abellan, J., Pardo, M.A., Tenza-Abril, A.J., 2017. Observed precipitation trend changes in the western Mediterranean region. Int. J. Climatol. 37 (S1), 1285-1296. 